\title{
HUBUNGAN ANTARA JENIS / BENTUK, UKURAN, DAN BAHAN FASILITAS DUDUK TERHADAP DURASI DUDUK PENGUNJUNG: KASUS STUDI CAFE EDUPLEX
}

\author{
RELATIONSHIPS BETWEEN TYPES, SIZES, AND \\ SITTING FACILITIES TO VISITOR SITTING \\ DURATION: STUDY CASE EDUPLEX CAFE
}

\author{
Aulia Fiya Maulida ${ }^{1}$, Ratri Wulandari ${ }^{2}$ \\ ${ }^{1}$ Universitas Telkom, maulidaaulia25@gmail.com \\ ${ }^{2}$ Universitas Telkom,wulandarir@telkomuniversity.ac.id
}

\begin{abstract}
Abstrak : Fasilitas duduk merupakan elemen penting yang berperan dalam menentukan tingkat kenyamanan di sebuah cafe atau restoran. Penelitian ini dilakukan untuk menganalisa lamanya pengunjung bertahan di dalam cafe sesuai fasilitas duduk yang digunakan dan mengambil kasus Cafe Eduplex di jalan Ir. H. Djuanda, Dago. Dalam penelitian ini membahas tentang hubungan antara jenis, ukuran dan bahan sebuah fasilitas duduk, terhadap frekuensi lamanya pengunjung yang datang di cafe tersebut. Metode penelitian yang digunakan adalah deskripsi kualitatif. Pertama, mengumpulkan data-data berupa teori tentang macam-macam jenis, ukuran standart dan bahan sebuah fasilitas duduk serta efeknya terhadap kenyamanan dan durasi waktu kedatangan pengunjung. Kedua, pengumpulan data lapangan dengan memperhatikan jenis, ukuran dan bahan fasilitas duduk yang ada pada cafe tersebut, serta memperhatikan jenis pengunjung dan perbedaan lamanya waktu pengunjung berada di cafe tersebut. Selanjutnya, membandingkan data-data yang sesuai dan berkesinambungan antara teori tertulis pada literatur dengan data lapangan yang terkumpul berupa jenis atau bentuk, ukuran dan bahan fasilitas duduk, serta lama waktu berkunjung. Hasil penelitian menunjukkan bahwa perbandingan antara hasil pengumpulan data lapangan dan literatur yang terkumpul sesuai. Jenis fasilitas duduk beserta ukuran dan bahannya berpengaruh dengan durasi waktu berkunjung. Karena adanya perbedaan rasa nyaman yang ditimbulkan oleh fasilitas duduk tersebut.
\end{abstract}

Kata kunci : Fasilitas duduk, Kenyamanan, Waktu berkunjung, Cafe

\begin{abstract}
Sitting facilities are an important element that plays a role in determining the level of comfort in a cafe or restaurant. This research was conducted to analyze the length of time visitors stayed in the cafe according to the sitting facilities used and took the case of Cafe Eduplex on Ir. H. Djuanda, Dago. This study discusses the relation between the type, size, and material of a sitting facility, to the frequency of visitors visiting the cafe. The research method that is used is a qualitative description. First, collecting data in the form of theories about the types, standard sizes, and materials of a sitting facility and their effect on the comfort and duration of visitors' arrival. Second, field data collection by paying attention to the type, size, and material of the sitting facilities at the cafe, and paying attention to the type of visitors and the difference in the length of time visitors are at the cafe. Next, compare the appropriate and continuous data between the written theory in the literature with the collected field data in the form or type, size, and material of the sitting facilities, as well as the length of time to visit. The results showed that the comparison between the results of field data collection and the literature collected as appropriate. The type of sitting facility and its size and material affect the duration of the visit. Because of the difference in comfort that is caused by the sitting facility.
\end{abstract}

Keywords : Sitting Facility, Comfortness, Time Visit, Cafe

\section{Pendahuluan}

Ruang publik kini sudah menjadi sebuah kebutuhan untuk masyarakat, khususnya kalangan remaja. Remaja membutuhkan sebuah tempat bekumpul untuk mengerjakan kesibukan mereka masing-masing, misalnya seperti mengerjakan tugas, rapat dan bahkan hanya berbincang-bincang menghabiskan waktu dengan teman-teman. Fasilitas wajib yang 
harus dimiliki sebuah ruang publik adalah fasilitas duduk. Karena fasilitas duduk dapat mempengaruhi kualitas kegiatan yang dilakukan oleh para pengunjung ruang publik tersebut. Misalnya, fasilitas duduk kursi yang keras akan membuat para pengunjung merasa lebih serius dan cocok untuk kegiatan rapat ataupun mengerjakan tugas, sedangkan fasilitas duduk sofa memberi kesan lebih rileks dan lebih cocok untuk para remaja yang ingin bercengkrama dengan teman-temannya. Ruang publik yang sedang ramai dikunjungi dan dicari oleh kalangan remaja karena keunikannya masing-masing adalah kafe.

Salah satu cafe yang berada di kota Bandung adalah cafe Eduplex yang berada di Jalan Ir.H.Juanda atau Jalan Dago. Cafe Eduplex memiliki akses yang cukup mudah karena berada di jalan raya dan juga dekat dengan beberapa perguruan tinggi di Bandung sehingga cafe ini dijadikan sebagai tempat wisata kuliner baik oleh wisatawan maupun mahasiswa. Cafe Eduplex biasa dipakai oleh para wisatawan maupun mahasiswa untuk melakukan aktivitas seperti rapat, mengerjakan tugas, diskusi, dan melakukan interaksi bersama teman-teman. Dalam hal ini wisatawan maupun mahasiswa merasa nyaman untuk menghabiskan waktu lama di cafe Eduplex, karena fasilitas yang disediakan cukup lengkap seperti fasilitas untuk duduk serta berdiskusi.

Fasilitas duduk adalah salah satu hal yang menciptakan kenyamanan di suatu tempat termasuk di cafe Eduplex. Terlihat dari pengunjung yang datang di cafe tersebut dapat merasakan tingkat kenyamanan yang berbeda-beda saat duduk di fasilitas duduk tertentu. Tingkat kenyamanan yang berbeda-beda menghasilkan durasi waktu duduk yang berbeda juga. Di Cafe Eduplex dapat ditemukan kecenderungan pengunjung yang menggunakan fasilitas duduk secara kurang tepat. Terdapat pengunjung yang tidur di bagian fasilitas duduk sofa Cafe Eduplex saat waktu sudah mulai larut malam. Cafe Eduplex dengan fasilitas 24 jam nya dan fasilitas duduk yang ada dapat menarik pengunjung untuk bertahan cukup lama di Cafe Eduplex. Di bagian fasilitas duduk lain, terdapat juga kecenderungan pengunjung untuk duduk dalam durasi waktu yang sebentar, seperti di area fasilitas duduk stool dan juga kursi kayu. Hal tersebut menyebabkan ketertarikan peneliti untuk melakukan penelitian tentang hubungan antara jenis/bentuk, ukuran, dan bahan fasilitas duduk terhadap durasi duduk pengunjung dengan studi kasus kafe eduplex. Penelitian tersebut bertujuan untuk mengangkat isu yang belum banyak diangkat yaitu isu keterkaitan antara kenyamanan dengan durasi pemakaian fasilitas duduk. Sehingga penelitian ini diharapkan dapat bermanfaat bagi penulis ataupun pembaca untuk menentukan jenis fasilitas duduk yang tepat sesuai dengan kenyamanan yang ingin diperoleh dan durasi waktu penggunaan yang diinginkan.

\section{Kasus Studi dan Metode Penelitian}

Kasus studi yang diangkat dalam penelitian ini didasarkan pada ketertarikan penulis akan fenomena yang ada. Terdapat perubahan fungsi dari sebuah fasilitas duduk yang seharusnya hanya digunakan untuk duduk, namun beralihfungsi menjadi tempat tidur dan juga perilaku pengguna yang suka berpindah tempat dari tempat duduk kayu ke tempat duduk sofa. Penelitian ini menggunakan metoda deskripsi kualitatif, yaitu dengan menjelaskan kondisi sebenarnya di lapangan untuk bagian penyajian data. Pertama, menggunakan metoda pengambilan data dengan mengumpulkan literatur dari jurnal-jurnal dan buku yang membahas tentang fasilitas duduk serta pengaruhnya terhadap kenyamanan. 
Data-data tersebut berupa teori tentang macam-macam jenis, ukuran standart dan bahan sebuah fasilitas duduk serta efeknya terhadap kenyamanan dan psikologi pengguna, yang menyebabkan adanya perbedaan durasi waktu berkunjung di sebuah cafe. Kedua, pengumpulan data lapangan dengan memperhatikan jenis, ukuran dan bahan fasilitas duduk yang ada pada cafe tersebut, serta memperhatikan jenis pengunjung dan perbedaan lamanya waktu pengunjung berada di cafe tersebut. Survey atau observasi langsung dilakukan dengan cara menganalisa dan memperhatikan secara langsung kejadian di lapangan, serta mengumpulkan dokumentasi berupa foto. Selanjutnya, membandingkan data-data yang sesuai dan berkesinambungan antara teori tertulis pada literatur, yang berisi tentang jenis atau bentuk, ukuran dan bahan fasilitas duduk serta efek yang ditimbulkannya dengan data lapangan yang terkumpul dari hasil survey atau observasi langsung berupa jenis atau bentuk, ukuran dan bahan fasilitas duduk yang ada di cafe tersebut, serta lama pengunjung berada di cafe tersebut.

\section{Hasil dan Temuan}

\subsection{Jenis Fasilitas Duduk}

Dari data dan pengamatan di lapangan, jenis fasilitas duduk yang terdapat di Cafe Eduplex terdiri dari tiga jenis, antara lain:

Tabel 1: Jenis Fasilitas Duduk di Cafe Eduplex

\begin{tabular}{|c|c|c|c|}
\hline Jenis & Stool & Kursi & Sofa \\
\hline & & & 1. Double Seater- \\
\hline & \multirow[t]{2}{*}{ 2. Loose Stool } & \multirow[t]{2}{*}{ 2. Kursi Santai } & $\begin{array}{l}\text { 2. Double Seater- } \\
\text { lengan } \\
\end{array}$ \\
\hline & & & $\begin{array}{l}\text { 3. Fainting Sofa - tanpa } \\
\text { sandaran }\end{array}$ \\
\hline
\end{tabular}

\subsection{Bahan atau Material Fasilitas Duduk}

Dari data dan pengamatan di lapangan, bahan atau material fasilitas duduk yang terdapat di Cafe Eduplex, antara lain:

Tabel 2: Bahan atau Material Fasilitas Duduk di Cafe Eduplex

\begin{tabular}{|c|c|l|l|l|}
\hline \multicolumn{2}{|c|}{$\begin{array}{c}\text { Jenis Fasilitas } \\
\text { Duduk }\end{array}$} & \multicolumn{3}{c|}{ Bahan atau Material } \\
\hline Jenis & Tipe & \multicolumn{1}{|c|}{ Kaki } & \multicolumn{1}{c|}{ Dudukan } & Sandaran \\
\hline Stool & Built-in & $\begin{array}{l}\text { Besi finishing } \\
\text { cat duco }\end{array}$ & $\begin{array}{l}\text { Kayu solid finishing } \\
\text { melamic }\end{array}$ & - \\
\cline { 2 - 5 } & Loose & $\begin{array}{l}\text { Besi finishing } \\
\text { cat duco }\end{array}$ & Besi finishing cat besi & - \\
\cline { 2 - 5 } & Loose & $\begin{array}{l}\text { Kayu solid } \\
\text { finishing } \\
\text { melamic }\end{array}$ & $\begin{array}{l}\text { Dudukan busa dengan } \\
\text { upholstery }\end{array}$ & - \\
\hline Kursi & Kursi & Kayu solid & Kayu & Kayu \\
\hline
\end{tabular}




\begin{tabular}{|c|c|c|c|c|}
\hline & $\begin{array}{l}\text { cafe/kursi } \\
\text { makan }\end{array}$ & $\begin{array}{l}\text { finishing } \\
\text { melamic }\end{array}$ & $\begin{array}{l}\text { finishing cat duco } \\
\text { glossy }\end{array}$ & $\begin{array}{l}\text { finishing cat } \\
\text { duco glossy }\end{array}$ \\
\hline & $\begin{array}{l}\text { Kursi } \\
\text { santai } \\
\text { (easy } \\
\text { chair) }\end{array}$ & $\begin{array}{ll}\text { Kayu } & \text { solid } \\
\text { finishing } & \\
\text { melamic } & \end{array}$ & $\begin{array}{l}\text { Kayu dengan busa lapis } \\
\text { upholstery }\end{array}$ & $\begin{array}{ll}\text { Rangka } & \text { kayu } \\
\text { dengan } & \text { busa } \\
\text { lapis } & \\
\text { upholstery } & \end{array}$ \\
\hline Sofa & $\begin{array}{l}\text { Double } \\
\text { Seater } \\
\text { dengan } \\
\text { sandaran } \\
\text { lengan }\end{array}$ & $\begin{array}{l}\text { Rangka kayu } \\
\text { solid }\end{array}$ & $\begin{array}{l}\text { Busa dan upholstery } \\
\text { kain } \\
\text { Poliester atau katun }\end{array}$ & $\begin{array}{l}\text { Busa dan } \\
\text { upholstery kain } \\
\text { Poliester atau } \\
\text { katun }\end{array}$ \\
\hline & $\begin{array}{l}\text { Double } \\
\text { Seater } \\
\text { tanpa } \\
\text { sandaran } \\
\text { lengan }\end{array}$ & $\begin{array}{l}\text { Rangka kayu } \\
\text { solid }\end{array}$ & $\begin{array}{l}\text { Busa dan upholstery } \\
\text { oscar/kulit sintetis }\end{array}$ & $\begin{array}{ll}\text { Busa dan } \\
\text { upholstery } \\
\text { oscar/kulit } \\
\text { sintetis }\end{array}$ \\
\hline & $\begin{array}{l}\text { Fainting } \\
\text { Sofa } \\
\text { tanpa } \\
\text { sandaran }\end{array}$ & $\begin{array}{l}\text { Rangka kayu } \\
\text { solid }\end{array}$ & $\begin{array}{l}\text { Busa dan upholstery } \\
\text { kain } \\
\text { katun }\end{array}$ & $\begin{array}{l}\text { Bantal busa } \\
\text { dengan pelapis } \\
\text { kain katun }\end{array}$ \\
\hline
\end{tabular}

\subsection{Pengamatan Durasi Waktu Berkunjung di Cafe Eduplex}

Pengamatan juga dilakukan terhadap durasi waktu pengunjung pada fasiltas duduk yang ada. Data di lapangan didapat melalui beberapa pengamatan, antara lain :

\subsubsection{Durasi Waktu Sebentar (0-2 jam)}

Pengamatan pertama dilakukan terhadap pengunjung yang duduk di stool built-in dengan material dudukan kayu. Pengunjung datang pada pukul 15.00, pada jeda waktu satu jam, pengunjung berdiri dan mencari tempat duduk lain yang kosong. Kemudian pengunjung berpindah setelah menemukan tempat duduk yang dirasa lebih nyaman. Sehingga perputaran pengunjung di fasilitas duduk jenis stool kayu sangat cepat. Pengguna yang duduk di stool dengan material kayu, memiliki kecenderungan untuk bertahan dalam waktu yang sebentar. Dugaan sementara hal ini terjadi karena penggunaan material kayu yang keras, membuat posisi duduk kurang nyaman karena menimbulkan tekanan pada bagian tulang duduk, paha dan tulang belakang sehingga membuat pengguna lebih cepat berpindah dari tempat duduknya.

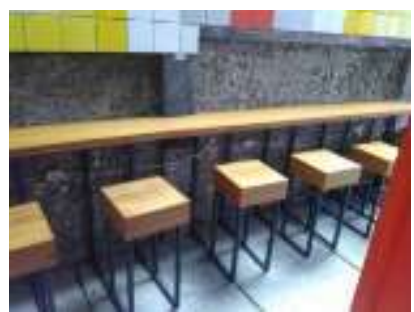

Gambar 1: Stool Built-in Kayu

Pengamatan kedua dilakukan terhadap pengunjung yang duduk di kursi cafe/kursi makan material kayu dengan sandaran punggung dan lengan. Pengunjung datang pada pukul 15.30, pada satu jam pertama pengunjung tetap pada posisinya, namun setelah satu jam setengah, ada kecenderungan perilaku pengunjung yang ingin berpindah atau pergi. Sehingga perputaran pengunjung di fasilitas duduk jenis kursi cafe sedikit cepat. 
Pengguna yang duduk di kursi cafe material kayu ini, memiliki batas rasa nyaman yang lebih lama dibanding pengguna stool kayu, karena kursi memiliki sandaran yang mampu menopang punggung pengguna. Penggunaan material kayu yang keras masih menimbulkan rasa kurang nyaman jika duduk terlalu lama. Ketidaknyamanan ini dirasakan di bagian tulang duduk dan paha.

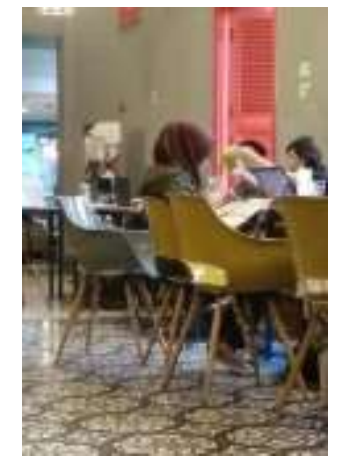

Gambar 2: Kursi cafe

\subsubsection{Durasi Lama (Lebih dari 2 jam)}

Pengamatan pertama dilakukan terhadap pengunjung yang duduk di sofa double seater dan easy chair dengan sandaran lengan bermaterial busa dan upholstery kain poliester. Untuk sofa double seater dan easy chair memiliki ketebalan busa dudukan sekitar $15 \mathrm{~cm}$ dengan tingkat kepadatan busa yang sedang. Pengunjung yang duduk di sofa ini mulai datang pada pukul 16.00. Pengunjung cenderung berlama-lama dan bersantai sambil makan, mengerjakan tugas atau berbincang bincang. Material yang empuk dan sejuk cenderung membuat penggunanya merasa nyaman dan betah. Sofa memiliki kedalaman tempat duduk sekitar $50-60 \mathrm{~cm}$ membuat penggunanya semakin nyaman sehingga pengguna dapat merebahkan badannya dan menyandarkan kepala di sandaran sofa. Dengan kondisi seperti ini pengunjung dapat bertahan di tempat duduknya sampai pukul 19.00. Namun ketika pengunjung datang di malam hari untuk tujuan mengerjakan tugas bersama, pengguna yang duduk di sofa double seater dengan sandaran dapat bertahan selama lebih dari empat jam hingga tertidur. Seperti pengamatan yang dilakukan pada pukul 22.00 hingga pukul 02.00 .
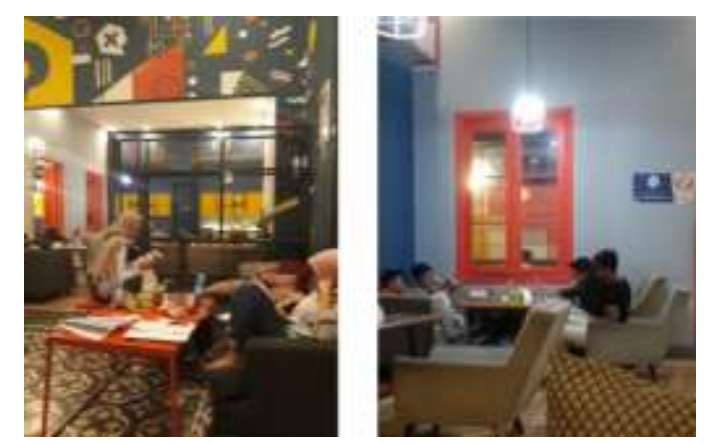

Gambar 3: Sofa double seater dan easy chair

Pengamatan kedua dilakukan terhadap pengunjung yang duduk di sofa double seater tanpa sandaran (fainting sofa) dengan material busa dan upholstery kain poliester. Untuk sofa double seater tanpa sandaran ini memiliki ketebalan busa dudukan sekitar $15 \mathrm{~cm}$ dengan tingkat kepadatan busa yang sedang. Pengunjung yang duduk di sofa ini datang pada pukul 15.00. Pengunjung yang datang dan duduk di sofa ini bertujuan 
untuk mengerjakan tugas. Dari hasil pengamatan, pengunjung sengaja memilih tempat yang sangat nyaman untuk mengerjakan tugas. Hal ini dibuktikan dengan durasi waktu pengunjung yang duduk dan mengerjakan tugas di sofa tersebut sampai pukul 19.00. Hal yang membuatnya merasa betah dan nyaman, adalah material sofa yang empuk dan sejuk. Selain itu dengan disediakannya bantal busa dengan lapisan kain katun yang tebal dan sejuk menambah kenyamanan pengguna duduk di sofa tersebut.
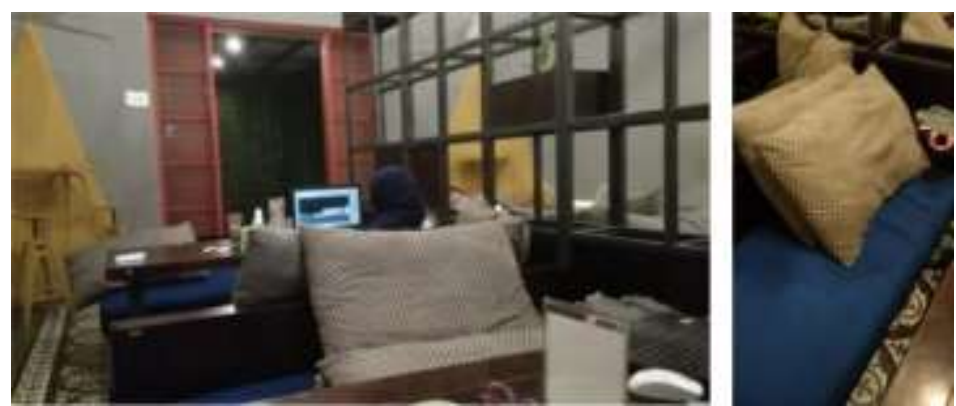

Gambar 4 : Fainting sofa double seater

Dari hasil pengamatan berdasarkan durasi waktu dan jenis fasilitas duduk yang digunakan oleh pengunjung, didapatkan hasil berupa tabel hubungan sebagai berikut:

Tabel 3: Hubungan Jenis, Bahan Fasilitas Duduk dan Durasi Waktu Pengunjung di Cafe Eduplex

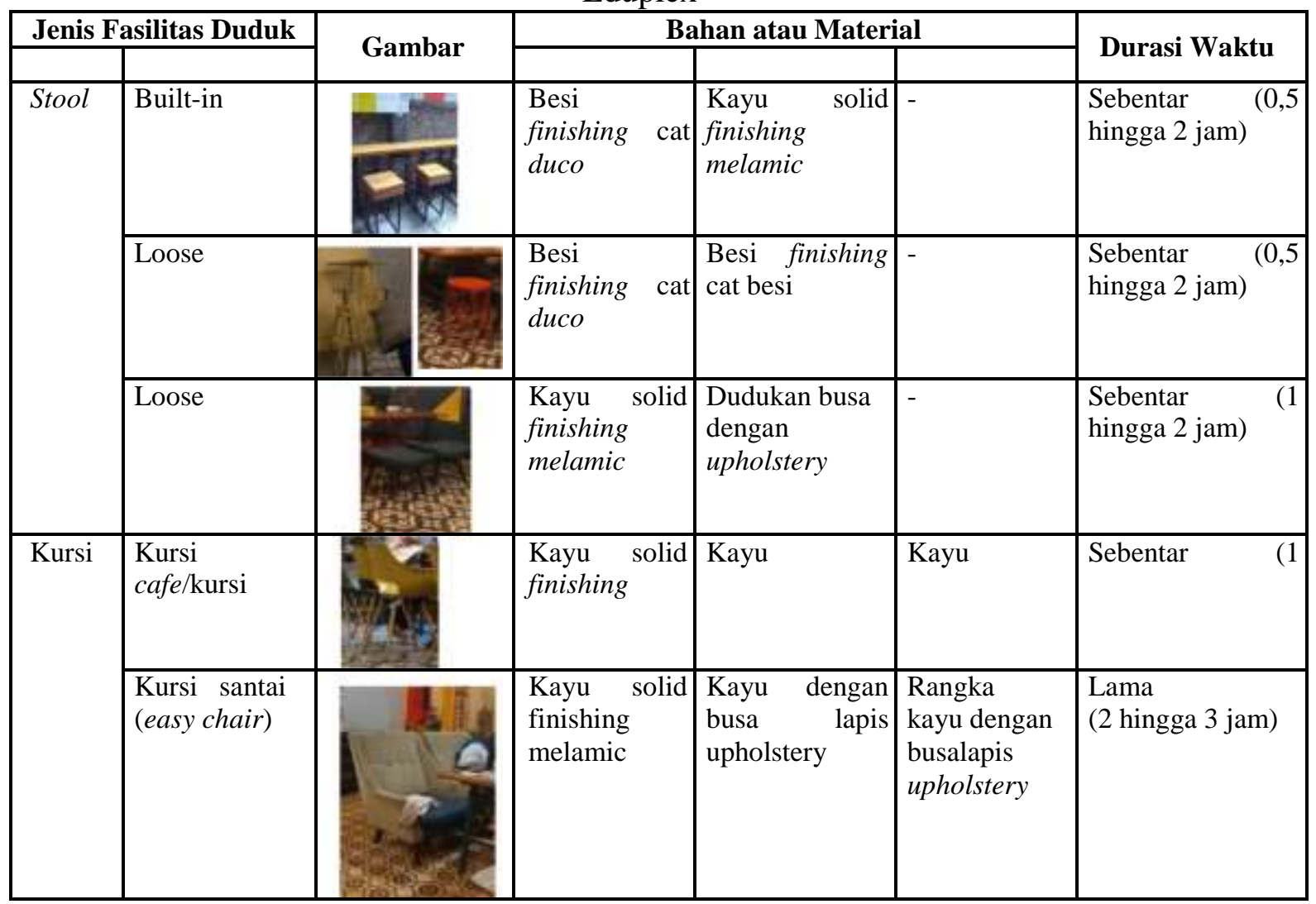




\begin{tabular}{|c|c|c|c|c|c|}
\hline \multirow[t]{3}{*}{ Sofa } & $\begin{array}{l}\text { Double } \\
\text { Seater } \\
\text { dengan } \\
\text { sandaran } \\
\text { lengan }\end{array}$ & $\begin{array}{l}\text { Rangka } \\
\text { kayu solid }\end{array}$ & $\begin{array}{l}\text { Busa dan } \\
\text { upholstery } \\
\text { kain } \\
\text { Poliester atau } \\
\text { katun }\end{array}$ & $\begin{array}{l}\text { Busa dan } \\
\text { upholstery } \\
\text { kain } \\
\text { Poliester } \\
\text { atau katun }\end{array}$ & $\begin{array}{l}\text { Lama } \\
\text { ( } 2 \text { hingga } 4 \text { jam })\end{array}$ \\
\hline & $\begin{array}{l}\text { Double } \\
\text { Seater } \\
\text { tanpa } \\
\text { sandaran } \\
\text { lengan }\end{array}$ & $\begin{array}{l}\text { Rangka } \\
\text { kayu solid }\end{array}$ & $\begin{array}{l}\text { Busa dan } \\
\text { upholstery } \\
\text { oscar/kulit } \\
\text { sintetis }\end{array}$ & $\begin{array}{l}\text { Busa dan } \\
\text { upholstery } \\
\text { oscar/kulit } \\
\text { sintetis }\end{array}$ & $\begin{array}{l}\text { Lama } \\
\text { ( } 2 \text { hingga } 4 \text { jam })\end{array}$ \\
\hline & $\begin{array}{l}\text { Fainting Sofa } \\
-\quad \operatorname{tanpa} \\
\text { sandaran }\end{array}$ & $\begin{array}{l}\text { Rangka } \\
\text { kayu solid }\end{array}$ & $\begin{array}{l}\text { Busa dan } \\
\text { upholstery } \\
\text { kain } \\
\text { katun }\end{array}$ & $\begin{array}{ll}\text { Bantal busa } \\
\text { dengan } \\
\text { pelapis kain } \\
\text { katun }\end{array}$ & $\begin{array}{l}\text { Lama } \\
(2 \text { hingga } 4 \text { jam })\end{array}$ \\
\hline
\end{tabular}

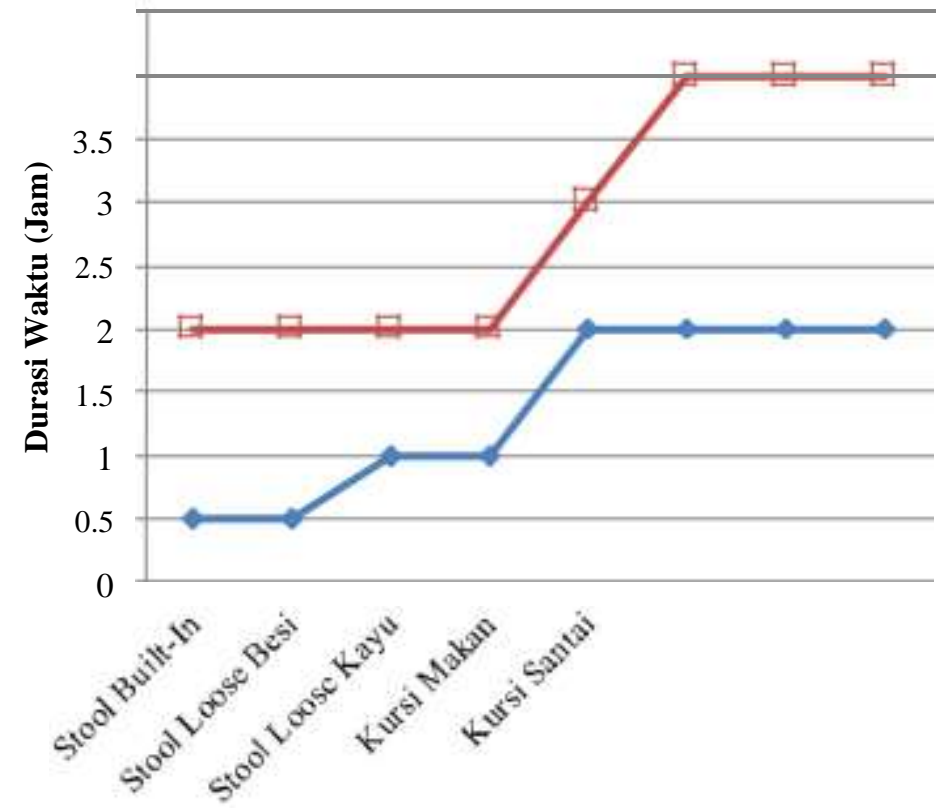

- Durasi Waktu Duduk Pengguna Tercepat (Jam)

$\because$ Durasi Waktu Duduk Pengguna Terlama (Jam)

\section{Jenis Fasilitas Duduk}

Diagram 1: Durasi Waktu Duduk Pengguna Fasilitas Duduk di Cafe Eduplex

\subsection{Pengamatan Tipe Pengunjung pada Setiap Area Jenis Fasilitas Duduk di Cafe Eduplex}

\subsubsection{Area Stool}

Berdasarkan pengamatan yang dilakukan dari pukul 15.00 hingga $22.00 \mathrm{WIB}$, area fasilitas duduk stool hanya digunakan sebagai tempat untuk bersinggah sebentar, dan didominansi oleh kalangan remaja dibanding dewasa. Untuk kalangan mahasiswa, mereka akan duduk sebentar untuk menuggu area kursi lain yang lebih nyaman kosong dan akan berpindah kesana. Hal itupun juga dilakukan oleh kami sendiri setiap berkunjung ke Cafe Eduplex hingga sekarang. Untuk kalangan dewasa, jarang terlihat duduk di area tersebut. Karena rata-rata tujuan pengunjung dewasa yang datang adalah 
meeting atau diskusi, maka mereka akan memilih untuk menyewa meja di lantai 2 atau berpindah ke tempat lain.

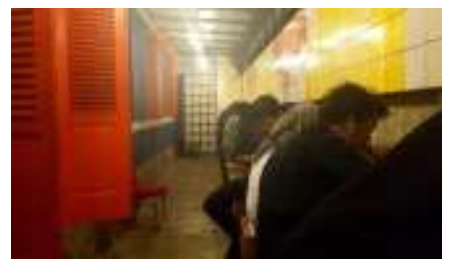

\subsubsection{Area Kursi Cafe}

Gambar 5: Pengunjung Area Stool

Menurut pengamatan yang dilakukan sejak pukul 15.00 hingga $22.00 \mathrm{WIB}$, jenis fasilitas duduk ini di dominansi oleh kalangan dewasa yang sedang membicarakan tentang pekerjaan. Area fasilitas duduk kursi cafe memiliki suasana yang lebih serius dibandingkan area tempat duduk lainnya, sehingga lebih cocok digunakan untuk meeting dan diskusi pekerjaan. Untuk kalangan remaja sendiri, ada beberapa pengunjung remaja yang duduk di area tempat duduk tersebut dan merekapun juga membuka laptop dan bukunya untuk belajar dan mengerjakan tugas. Tetapi, berbeda dengan pengunjung dewasa yang hanya bertujuan untuk meeting lalu pulang, pengunjung kalangan remaja akan menunggu sampai area kursi lain yang lebih nyaman kosong dan berpindah tempat atau dapat disimpulkan bahwa jenis fasilitas duduk kusi cafe juga digunakan sebagai tempat bersinggah sebentar oleh para remaja.

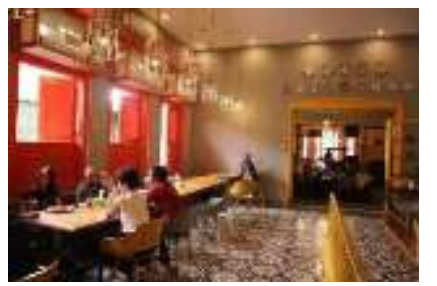

Gambar 6: Pengunjung Area Kursi Cafe

\subsubsection{Area Sofa Double Seater dan Easy Chair}

Menurut pengamatan yang dilakukan, area sofa double seater dan easy chair didominansi oleh kalangan remaja. Mereka lebih memilih area yang santai dan nyaman untuk mengerjakan tugas ataupun belajar. Bahkan alasan lainnya adalah kalangan remaja dapat singgah selama 24 jam dan tidur di cafe dengan nyaman di area ini. Sedangkan untuk kalangan dewasa jarang terlihat menduduki area ini, karena selalu penuh atau kalah cepat dengan pengunjung remaja. Beberapa pengunjung dewasa yang memilih duduk di area sofa double seater dan easy chair hanya ingin merasakan kenyaman yang lebih dan bersistirahat sejenak, setelah itu mereka akan langsung pulang atau kembali ke kantor tanpa membuang waktunya. Berbeda dengan tujuan para pengunjung remaja yang ingin nongkrong, berbincang-bincang hingga tidur.

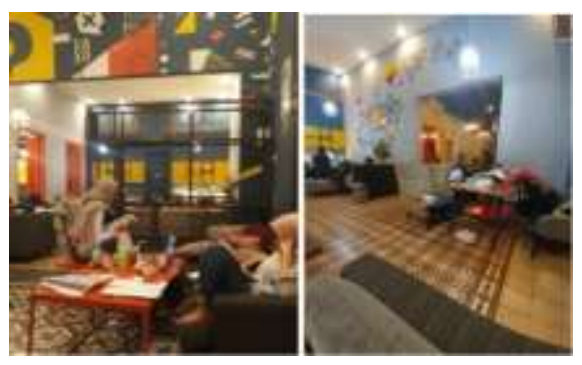

Gambar 7: Pengunjung Area Sofa Double Seater dan Easy Chair 


\subsubsection{Area Fainting Sofa Double Seater}

Menurut pengamatan yang dilakukan, jelas sekali bahwa area ini didominansi oleh kalangan remaja. Bahkan hampir tidak ada pengunjung dewasa yang duduk di area ini. Sejak pertama kami datang, area fainting sofa double seater ini sudah dipenuhi oleh pengunjung yang tidur, berselonjor, hingga berbincang-bincang sambil membuka laptop di depannya. Pengunjung tersebut bertahan sangat lama hingga mencapai 4 atau 5 jam lamanya, apalagi pengunjung yang tidur bisa menghabiskan lebih dari 12 jam di cafe tersebut. Beberapa kalangan dewasa yang singgah di area tempat duduk ini tidak membicarakan pekerjaan mereka atau pun mengerjakan tugas mereka. Mereka hanya singgah untuk makan, bersantai dan berbincang - bincang setelah itu mereka akan pulang atau kembali ke kantor. Karena, area fainting sofa double seater ini memiliki suasana yang santai hingga membuat pengunjung mengantuk, sehingga tidak cocok bagi orang dewasa yang berkunjung dengan tujuan meeting atau diskusi pekerjaan.

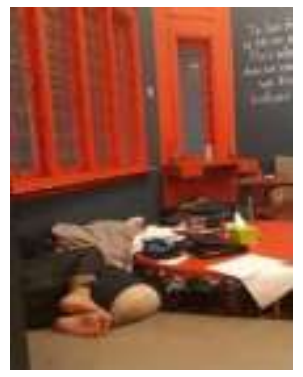

Gambar 8: Pengunjung Area Fainting Sofa Double Seater

\section{Diskusi/Pembahasan}

Dari data hasil pengamatan yang ada, dilanjutkan dengan pembandingan data dengan literatur yang berkaitan. Data literatur yang menjadi pembanding data lampangan yang ada, antara lain:

\subsection{Jenis Fasilitas Duduk}

Terdapat beberapa jenis fasilitas duduk yang ada di beberapa tempat seperti kursi yang merupakan furniture idealnya memiliki 4 kaki, dapat digunakan untuk duduk dan bersantai, untuk 1 orang. Adapun jenis-jenis kursi menurut (Aryanto, 2012) antara lain, kursi biasa, armchair, reclainer chair, wheel chair, easy chair. Selain itu kursi juga dapat divariasikan dengan memberikan berbagai finishing juga seperti menambahkan busa. Selain kursi jenis-jenis fasilitas duduk yang ada yaitu sofa.

Sofa adalah fasilitas duduk yang dapat digunakan oleh 2 sampai dengan 3 orang atau lebih, serta bisa memiliki armrest ataupun tidak. Sofa biasanya ditempatkan di tempat yang biasa digunakan untuk melakukan sebuah aktivitas dan tempat yang biasa digunakan untuk istirahat seperti di kamar tidur. Sofa identik dengan tempat duduk berkenyamanan tinggi dan cushion yang empuk. Macam-macam sofa terdiri dari sofa double, sofa 3 orang, sofabed, fainting sofa (tanpa senderan), the canape (sofa dengan ornamen). Untuk fungsi, sofa biasa digunakan untuk duduk dan tidur (Aryanto, 2012). Selain kursi dan sofa terdapat jenis lain untuk fasilitas duduk yaitu stool. 
Stool adalah sebuah fasilitas duduk tanpa senderan dan armrest yang memiliki variasi jumlah kaki dan hanya untuk 1 orang. Biasanya diletakkan di ruang makan seperti cafe, restoran, berpasangan dengan sofa dan kursi. Terdapat berbagai macam jenis stool diantara lain terdapat stool biasa dan bar stool. Bar stool sendiri memiliki ukuran yang lebih tinggi dari stool biasa (Gloag, 1962).

\subsection{Material Fasilitas Duduk}

Menurut (Aryanto, 2012) terdapat jenis- jenis material pokok, yaitu alami dan buatan. Material pokok alami yaitu terbuat dari bahan-bahan seperti kayu (yang bersifat klasik), rotan (yang bersifat lentur, mudah di tekuk, diameternya bervariasi), dan bambu (yang berciri berbatang, beruas, kuat, dan tinggi). Sedangkan untuk material pokok buatan yaitu terbuatdari bahan-bahan seperti kayu lapis (plywood), fiber, MDF, dan logam. Dalam hal ini material pokok tersebut banyak digunakan sebagai furniture di restoran maupun cafe.

Ciri-ciri furniture yang banyak digunakan di restoran atau kafe biasanya berbentuk geometris, sedangkan untuk material yang digunakan berbahan keras karena untuk menumpu beban di atasnya. Fungsi lain yang ditujukan untuk penggunaan furnitur keras yaitu agar pelanggan tidak terlalu lama berada di sana dan dapat bergantian dengan pelanggan lain. Penggunaan material kayu, besi, dan plywood, biasanya digunakan pada tempat yang memilki tema alami serta suasana outdoor. Finishing yang digunakan juga menggunakan bahan-bahan alami seperti cat, melamin, dan pelitur. Penggunaan material yang lebih modern seperti plastik fiber, bahan-bahan empuk, plywood, dan stainless steel biasanya ditempatkan di ruangan indoor, untuk menciptakan suasana cozy, santai dan nyaman (Arief, 2013). Material fasilitas duduk selain material pokok ada juga material lain yaitu material pelapis kursi atau sofa.

Secara umum bahan pelapis kursi atau sofa terdiri dari tiga macam, yaitu kain (fabric), kulit asli (leather), dan kulit imitasi (synthetic leather). Menurut (Artdina (2014) dalam Fatimah, 2013), kain banyak dipakai sebagai bahan pelapis sofa karena memiliki kelebihan dalam beragamnya warna, tekstur, motif dan jenis.. Beberapa jenis bahan kain yang beredar dipasaran yaitu Cotton/Katun, kain ini relatif nyaman, dingin, harga terjangkau, mudah robek, warna tidak tahan lama, rentan terhadap noda dan air. Selain itu bahan kain Polyester yang memilki sifat mudah terlipat, mudah menyerap minyak, cukup awet, dan rentan terhadap air. Bahan jenis Linen memiliki tekstur yang lembut, terbuat dari serat alami, lebih kuat dibandingkan katun, mudah berkerut, dan panas di kulit. Bahan jenis Chenille memiliki tekstur lembut, mirip rajutan, serat rapat, awet, susah dibersihkan, rentan terhadap air. Sedangkan untuk bahan Rayon/viscose memilki sifat kuat, tekstur halus, mudah terbakar, rentan terhadap air (Fatimah, 2013).

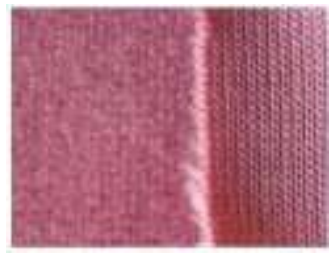

Gambar 9: Contoh Polyester 


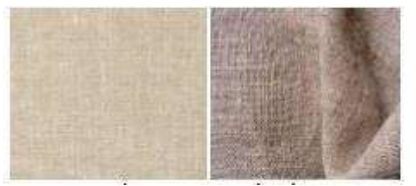

Gambar 9: Contoh Linen

Gambar 10: Contoh Rayon

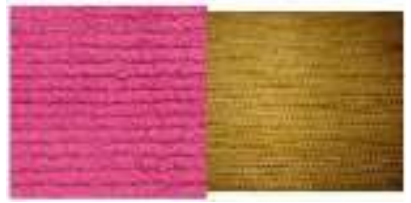

Gambar 11: Contoh Chenille

\subsection{Standar Kenyamanan/Ergonomi Fasilitas Duduk}

Kursi biasa yang ergonomis yaitu yang memiliki kedalaman kursi yang nyaman biasanya adalah $42 \mathrm{~cm}$, posisi kaki masih menapak di lantai, kedalaman dudukan biasanya dibuat $48 \mathrm{~cm}$, agar punggung bagian bawah dapat menempel ke sandaran kursi, dan lebar kursi sekitar 45cm (Wicaksono, 2014).

Selain itu kursi santai yang ergonomis yaitu yang memiliki posisi tubuh yang duduk hampir berbaring, dengan ketinggian dudukan hanya sekitar $36-38 \mathrm{~cm}$, kedalaman kursi sekitar 54- 58cm, dan lebar sekitar 70-80cm, dengan bantalan yang tebal (Wicaksono, 2014).

Sedangkan untuk sofa yang ergonomis adalah sofa yang harus memenuhi 2 fungsi yaitu duduk dan hampir berbaring, kedalaman dudukan sofa $58 \mathrm{~cm}$, sedangkan tempat untuk posisi hampir berbaring adalah $75-85 \mathrm{~cm}$ sehingga harus menggunakan bantalan yang besar, lebar sofa sekitar $160 \mathrm{~cm}$, untuk lebar dalam ditambah senderan tangan $15 \mathrm{~cm}$ di kedua sisinya, dan lebar keseluruhan sekitar 190cm (Wicaksono, 2014).

Menurut Leibrock dan Harris dalam bukunya Design Details for Health, sofa lebih direkomendasikan kepada orang - orang yang ingin bersantai atau meredakan stress. Sofa memiliki busa yang empuk dan cocok untuk pengguna yang ingin merasakan kenyamanan yang lebih. Sofa dapat mengurangi rasa nyeri di punggung dan tulang yang di sebabkan oleh permukaan tempat duduk yang keras. Bukan hanya itu saja, kain pelapis pada sofa dapat membuat kulit lebih mudah bernafas dibanding kayu polos biasa. Seperti contohnya kain wol dan rayon. Tetapi sofa tersebut harus memenuhi beberapa syarat kenyamanan dan kesehatannya, seperti adanya armrest, bahan kain yang sejuk, dan kepadatan busa yang tepat (tidak terlalu keras dan tidak terlalu empuk). (Leibrock dan Harris, 2011) 


\section{Kesimpulan}

Dari hasil penelitian yang dilakukan di cafe Eduplex pada tanggal 24 Maret 2018 pukul 14.00-20.00 WIB, 21 April 2018 pukul 22.00-04.00 WIB dan 20 Desember 2018 pukul 15.00-22.00 WIB, bahwa perbandingan hasil pengumpulan data literatur dan data lapangan sesuai. Fasilitas duduk yang memiliki aspek kenyamanan dalam ukuran, jenis dan bahannya akan mempengaruhi durasi waktu penggunaan fasilitas duduk ketika berkunjung ke cafe Eduplex.

Sesuai dengan literatur mengenai jenis-jenis fasilitas duduk yang mengatakan bahwa kursi dan stool cocok untuk ruangan beraktifitas (Gloag, 1962) dan sofa adalah fasilitas duduk yang cocok untuk beristirahat, tidur, serta duduk (Aryanto, 2012) telah membuktikan bahwa data literatur sesuai dengan data hasil penelitian di lapangan, yang dibuktikan dengan adanya pengunjung yang dapat bertahan selama 2 jam atau lebih di sofa untuk duduk, bersantai, bahkan tertidur. Sedangkan sesuai dengan jenis materialnya, material dengan penggunaan bahan yang empuk seperti padding cocok untuk kafe bertemakan cozy dan nyaman, yang membuat pengunjung bertahan lebih lama (Arief, 2013), ini juga sudah membuktikan kesamaannya dengan data lapangan yang diambil. Untuk material tambahan atau finishing, bahan katun merupakan bahan ternyaman yang biasa digunakan untuk finishing fasilitas duduk karena sifatnya yang dingin (Fatimah, 2013), sesuai dengan data lapangan yang dibuktikan dengan adanya pengunjung yang duduk di sofa dengan padding berlapis upholstery dan bantal berlapis kain katun bertahan lebih lama dari pengunjung lainnya, yaitu mencapai 4 jam lamanya.

Dengan demikian, terbukti bahwa bentuk dan material suatu fasilitas duduk mempengaruhi kegiatan dan durasi duduk penggunanya. Dengan fasilitas duduk bentuk tertentu, dapat merubah kegiatan pengguna yang semula digunakan hanya untuk duduk menjadi tempat bersantai bahkan tidur seperti pada fasilitas duduk sofa. Untuk faktor ergonomi, fasilitas duduk dengan sandaran yang hampir berbaring seperti kursi santai dan sofa memiliki durasi ketahanan pengunjung lebih lama dibanding kursi makan / kafe yang bersenderan lebih tegap dan stool yang tidak memiliki sandaran. Terakhir, menurut literatur (Leibrock dan Harris, 2011) mengatakan bahwa sofa dapat mengurangi nyeri pada punggung dan tulang duduk yang disebabkan oleh permukaan tempat duduk yang keras, sehingga pengunjung yang berada di sofa akan merasa lebih nyaman dan aman. Terbukti pada hasil pengamatan dengan membandingkan data literatur di atas, pada fasilitas duduk dengan material dudukan yang keras, membuat pengguna tidak ingin berlama-lama duduk di kursi tersebut. Durasi yang singkat pada penggunaan fasilitas duduk seperti itu diakibatkan oleh adanya rasa kurang nyaman pada punggung dan tulang duduk dari material dudukan di fasilitas duduk seperti stool kayu. Dari analisis mengenai jenis dan material fasilitas duduk di atas menghasilkan kesimpulan bahwa fasilitas duduk yang nyaman untuk digunakan dalam waktu lama seperti sofa, kursi santai yang memiliki material empuk, didominasi oleh pengguna usia remaja terutama pelajar atau mahasiswa. Pengguna usia remaja dapat menghabiskan waktunya berjam-jam untuk sekedar berbincang, mengerjakan tugas hingga tertidur. Sedangkan untuk fasilitas duduk yang kurang nyaman jika digunakan dalam waktu lama seperti stool kayu, kursi makan, yang memiliki dudukan keras, didominasi oleh pengguna kalangan dewasa yang biasanya hanya bersinggah untuk sekedar makan sambil melakukan meeting sederhana. Sehingga mereka tidak akan menghabiskan 
waktu terlalu lama untuk berada di cafe Eduplex ini.

Dari hasil dan kesimpulan penelitian ini, diharapkan dapat bermanfaat bagi penulis ataupun pembaca untuk menentukan jenis fasilitas duduk yang tepat sesuai dengan kenyamanan yang ingin diperoleh dan durasi waktu penggunaan yang diinginkan.

\section{Daftar Pustaka}

[1] Arief, B. d. (2013). "Penggunaan Material Furnitur Sebagai Pendukung Tema Pada Desain Interior Nanny's Pavillon Di Bandung.“ Jurnal Online ITENAS Bandung.

[2] Artdina (2014) dalam Fatimah, D. d. (2013). "Pengaruh Tactile Terhadap Keputusan Pembeli Dalam Memilih Produk Mebel (Studi Kasus Fasilitas Duduk Sofa). “ Bandung: Fakultas Desain, Universitas Komputer Indonesia.

[3] Aryanto, Y. (2012). 173 Meja dan Kursi. Jakarta: Griya Kreasi.

[4] Gloag, J. (1962). A Short Dictionary of Furniture. London: Allen \& Unwin.

[5] Leibrock, C. A dan Harris, D. D. (2011). Design Detail for Health: Making the Most of Design's Healing Potential. Hoboken, New Jersey: John Wiley \& Sons, Inc.

[6] Tesna, A. d. (2014). Teori Interior.

[7] Wicaksono, A. A. (2014). Teori Interior. Jakarta: Griya Kreasi. 